\title{
The Internalization of Pancasila Values through Ethics and Character Education of Nations (Balinese Social-Cultural Perspective)
}

\section{Pande Wayan Renawati}

\author{
Magister Brahma Widya Program Pascasarjana Universitas Hindu Negeri IGB Sugriwa \\ Denpasar \\ panderena@gmail.com
}

\section{Article History}

accepted 24/03/2021

\begin{abstract}
Indonesia is a country with a massive cultural diversity in every region. The cultural community certainly has its own characteristics to show their respective traditions with the natural forces of the region both real (sekala) and intangible (niskala). In that case, to live the socio -cultural life is certainly not independent of the procedures, attitudes and ethics when dealing with society. now, ethical attitudes in character seem almost extinct and neglected. This is becoming more viral with the participation of unethical attitudes by young people through youtube content, InstaGram, and other electronic media that have been rapidly developing lately. So it is necessary the role of parents, the role of educators, and the role of the government to be able to filter the food on the media and always direct the students to always improve the values of Pancasila as the basis of being ethical as a moral teaching. In this case, Pancasila will be discussed through ethical education from the point of view of Balinese Theology and Culture.

Keywords: Pancasila, ethics and character
\end{abstract}

\begin{abstract}
Abstrak
Indonesia merupakan negara dengan berragam budaya yang adi luhung secara massif di setiap daerah. Masyarakat budaya tersebut tentu memiliki ciri khas tersendiri untuk menunjukkan tradisi masing-masing dengan kekuatan alam daerahnya baik secara nyata (sekala) maupun tidak nyata (niskala). Dalam hal itu, untuk menjalani kehidupan sosial budaya tersebut tentu tidak terlepas dari tata cara, sikap maupun etika ketika berhadapan dengan masyarakat. kini, sikap etika dalam budi pekerti terlihat hampir punah dan terabaikan. Hal ini makin viral dengan diikutinya sikap-sikap di luar etika oleh muda-mudi melalui konten youtube, InstaGram, serta media elektronik lainnya yang makin pesat perkembangannya akhir-akhir ini. Sehingga diperlukan peran orang tua, peran para pendidik, serta peran pemerintah untuk dapat menyaring sajian pada media tersebut dan selalu mengarahkan kepada para didikannya untuk selalu meningkatkan nilai-nilai Pancasila sebagai dasar bersikap penuh etika sebagai ajaran budi pekerti. Dalam hal ini akan dibahas Pancasila melalui pendidikan etika budi pekerti dari sudut pandang Teologi dan Budaya Bali.
\end{abstract}

Kata kunci: Pancasila, etika dan budi pekerti

Social, Humanities, and Education Studies (SHEs): Conference Series https://jurnal.uns.ac.id/shes

p-ISSN 2620-9284

e-ISSN 2620-9292 


\section{PENDAHULUAN}

Dasar negara Indonesia adalah Pancasila, panca berarti lima dan sila berarti dasar. Jadi dimaknai sebagai lima dasar untuk mewujudkan Indonesia ini menjadi mulia, makmur dan terkenal di segala penjuru dunia dengan ciri khasnya yang membedakan dengan negara lain di dunia. Bila ditelusuri lebih jauh maka nilai- nilai yang terkandung dalam Pancasila itu memberikan dorongan semangat bagi seluruh jiwa bangsa Indonesia yang dituangkan dan diimplementasikan dalam kehidupan sehari-hari. Semua didasarkan atas kesadaran berjiwa dan semangat hidup untuk memajukan bangsa ini. Masyarakat Indonesia seharusnya bersyukur dengan segala hal yang ada di negara ini dengan kekayaan alam yang melimpah ruah, ada yang bisa diterima langsung dengan mengambilnya dari alam atau mesti mengolahnya terlebih dahulu. Selain kekayaan alam juga negara Indonesia kaya akan kebudayaannya. Masing-masing budaya mempunyai nilai, makna dan fungsi tersendiri.

Penduduk Indonesia dengan berragam budaya yang mempunyai nilai- nilai adat yang tinggi di masing- masing pulau dan daerah di Indonesia. Setiap budaya selalu mengajarkan hal-hal yang baik untuk menjadikan masyarakatnya yang bisa memahami nilai- nilai budi pekerti dan beretika dalam menghadapi masyarakat dan benar-benar tidak bertentangan dengan Pancasila. Nilai etika dan budi pekerti itu pada masa kini sudah mulai luntur dengan kecanggihan teknologi yang berkembang pesat menguasai bumi. Menurut Sisil (March 3, 2018) disebutkan bahwa Peran teknologi dewasa ini dalam mempengaruhi perubahan manusia bukanlah sesuatu hal yang unik dan baru yang perlu dipertanyakan lagi, jika dilihat dari sisi kehidupan di era modern ini, manusia tidak akan mampu hidup tanpa teknologi. Hal itu berimplikasi pada berbagai bentuk model dan konten dari setiap gadget dalam bentuk dan ukuran yang berbeda dan isinya juga mengandung berbagai hal ada yang positif nilainya ada pula yang negatif yang disajikan secara vulgar yang sepatutnya hanya bisa diketahui oleh orang dewasa saja namun ternyata bisa disaksikan juga oleh anak-anak dibawah umur sehingga berimplikasi pada kejiwaan dan sikapnya dalam hidup sehari-hari. Selain hal itu juga dengan berbagai sikap atau kreasi anak muda atau sejenisnya berakibat sudah makin berubah dengan menurunnya jiwa Pancasila yang tumbuh dalam jiwa masing-masing ditambah lagi ajaran budi pekerti yang sudah semakin ditinggalkan, beberapa darinya sudah tidak mengenal sopan santun, tidak beretika dalam bersikap yang intinya ajaran budi pekerti itu sudah tidak relevan di masa kini baginya. Berdasarkan sikap-sikap tersebut yang sesungguhnya tidak mencerminkan nilai-nilai Pancasila secara internal terkait dengan adat dan budaya setempat. Untuk itu diperlukan peran pemerintah dan masyarakat secara menyeluruh untuk saling bahu - membahu memahami lebih luas setiap gerak perbedaan yang ada di lingkungannya masing-masing, prihal yang dipandang cukup penting untuk dijadikan dasar pencarian terhadap solusi permasalahannya, sehingga kiranya mampu diatasi dengan baik dan bisa melindungi generasi penerus bangsa yang bermartabat.

Sehubungan dengan hal itu, adat dan tradisi di masing-masing daerah diketahui bersama sangat berbeda. Dalam hal ini akan dibicarakan terkait dengan aspek sosial dan budaya Bali. Mengenai adat dan budaya Bali pun tidak sama untuk di masingmasing kabupaten. Untuk di setiap desa sudah berbeda walau bernaung di bawah satu kabupaten. Hal itu juga berimplikasi pada sikap masing-masing individu baik lewat ucapan, kejiwaannya juga perkembangan teknologi yang mendukung di masingmasing desa tersebut. Menurut sastra-sastra Hindu ada beberapa hal yang bisa dijadikan acuan dalam pemecahan permasalahan dihubungkan dengan aspek sosial dan budaya sebagai berikut. (1) bagaimana bentuk internalisasi nilai-nilai luhur Pancasila melalui pendidikan etika dan budi pekerti bangsa? (2) bagaimana fungsi nilai-nilai luhur Pancasila tersebut? (3) Bagaimana makna yang tersirat dalam internalisasi nilai-nilai luhur Pancasila itu? 


\section{METODE}

Metode merupakan cara untuk menyelesaikan suatu permasalahan secara ilmiah, signifikan dan relevan dengan hal yang menjadi focus untuk solusinya. Menurut Agung Prasetyo (Sept. 2016) disebutkan bahwa metode penelitian deskriptif kualitatif merupakan salah satu dari jenis penelitian yang termasuk dalam jenis penelitian kualitatif. Adapun tujuan dari penelitian ini adalah untuk mengungkapkan kejadian atau fakta, keadaan, fenomena yang sebenarnya, dengan variabel yang terjadi saat penelitian berlangsung dengan menyuguhkan dan menafsirkan yang sebenarnya, serta menguraikan data yang bersangkutan dengan situasi yang sedang terjadi, mengenai sikap serta pandangan dalam fakta di masyarakat, juga terkait dengan pertentangan antara dua keadaan atau lebih, hubungan antar variable yang timbul, perbedaan antar fakta yang ada serta pengaruhnya terhadap suatu kondisi, dan sebagainya. Sehingga melalui metode ini diharapkan mampu untuk mengatasi fenomena yang ada dalam kaitannya dengan internalisasi nilai-nilai luhur Pancasila yang disampaikan melalui paparan atau secara deskriptif sesuai dengan pemahaman etika dan ajaran budi pekerti dalam aspek sosial budaya Hindu di Bali benar- benar bermanfaat bagi berbagai pihak pembaca pada umumnya.

\section{HASIL DAN PEMBAHASAN}

Mengenai permasalahan tersebut di atas akan dibahas dalam kaitannya dengan sosial dan budaya Bali sebagai berikut.

1. Bentuk internalisasi nilai-nilai luhur Pancasila melalui pendidikan etika dan budi pekerti bangsa dalam perspektif sosial dan budaya Bali.

Bali memiliki nilai- nilai sosial budaya yang mesti dilestarikan sebagai peninggalan leluhur di masa lampau. Kekayaan budaya tersebut sangat diperhatikan bahkan disakralkan. Ajaran budi pekerti sesungguhnya sudah melekat di hati sanubari setiap masyarakat sebagai ajaran etika yang berbudi luhur dari masa lalu yang diajarkan dalam kehidupan sehari-hari. Seperti halnya ajaran yang sudah mentradisi yaitu. Jangan duduk di bantal nanti akan menjadi bisul, karena bantal pada umumnya hanya untuk kepala bukan sebagai tempat duduk. Jangan memotong sesuatu dalam satu talenan akan berakibat meninggalnya barengan. Kalau melewati tempat saat orang duduk sebaiknya permisi atau ijin dahulu, namun di masa kini terkadang anak-anak hanya lewat saja tanpa ijin dahulu. Hal yang lain lagi terkadang anak sudah berani melawan orang tuanya, anak bersikap kasar pada orang yang dituakan, serta masih banyak lagi yang sejenis mempunyai makna yang berbeda pula. Dari sikap-sikap tersebut tidak disadari sesungguhnya bersyukur dilahirkan sebagai manusia yang mempunyai daya pikir dibandingkan hewan dan tumbuh-tumbuhan. Bersyukurnya menjadi manusia tercermin dalam kitab Sarascamuscaya sloka 3 menurut Kadjeng (2005 : 8) disebutkan bahwa Sebagai mahluk hidup yang mempunyai pikiran dari mahluk lainnya di dunia, kelahiran sebagai manusia niscaya mempunyai keinginan untuk berbuat yang baik juga buruk diakibatkan oleh sesuatu, segala perbuatan yang buruk akan menjadi hancur lebur dengan melakukan perbuatan yang baik, sehingga kelahiran sebagai manusia itu sangat berguna (berpahala) lahir menjadi manusia.

Dari sloka di atas diharapkan agar mempunyai rasa penuh bersyukur untuk menjadi manusia yang bisa melebur kejahatan menjadi kebaikan di dunia ini sehingga tidak menjadi penghuni neraka atau dalam kehidupan selalu menemui kesengsaraan. Hal ini disebabkan karena manusia mempunya kelebihan pikiran dibandingkan dengan hewan dan tumbuhan. Dengan adanya kelebihan mampu menentukan hal mana yang baik atau yang buruk sering disebut Wiweka Jnana.Maknanya disampaikan menurut https://brainly.co.id/tugas/6929879 Wiweka merupakan sebuah kebijaksanaan atau daya nalar seseorang untuk mendapat pertimbangan dalam berbagai hal antara lain; benar dan salah, amal dan dosa, 
baik dan buruk (subha Asubha Karma) sejati dan palsu. Wiweka sebagai dasar dasar etika agama hindu disebutkan bahwa,

Wiweka ini sangat menentukan 'keputusan hati' yang disebut "Nisacaya Jnana." Melalui penentuan sikap tersebut maka bisa melebur derita kesengsaraan untuk mendapatkan kebahagiaan jasmani dan rohani. Sehubungan dengan hal itu, Pancasila pun selalu mengajarkan sikap dan perbuatan baiknya melalui P4 (Pedoman, Penghayatan dan Pengamalan Pancasila). Nilai-nilai yang tercermin di dalamnya cukup kuat untuk menjadi masyarakat Indonesia yang penuh persatuan, nilai kemanusiaan yang tinggi, utamanya nilai-nilai pemahaman akan Pancasila yang sangat tinggi pula, namun seiring perputaran zaman, pemahaman P4 itu tidak begitu terlihat kembali. Sehingga timbul gerakan anarkhi melawan Pancasila hingga tidak percaya akan Pancasila kembali. Namun seiring dengan melajunya waktu maka sebagai seleksi alam, Pancasila kembali dijadikan pelajaran baik di sekolah-sekolah maupun di kampus-kampus. Sehubungan dengan hal itu untuk menguatkan diri memahami Pancasila itu dalam benak masing-masing individu, menurut Wiana (2004: 89) dalam kitab Niti sastra Kekawin VIII.3 disebutkan lima perbuatan utama sebagai jasa leluhur kepada keturunannya sehingga generasi yang dilahirkan kelak menjadi manusia yang seutuhnya hormat pada aturan negara melalui lima perbuatan jasa leluhur yang disebut Panca Widha, diantaranya :

a) Sang ametuaken, orang tua yang melahirkan kita ke dunia ini;

b) Sang maweh binojana, orang yang memberikan kita berupa makan dan minum untuk

c) bisa bertahan hidup di dunia, bisa orang tua, bisa juga orang lain;

d) Sang matulung urip rikalaning baya, orang yang memberikan keselamatan nyawa kita saat

e) menghadapi mara bahaya, bisa dilakukan oleh orang tua, teman atau pun melalui bantuan

f) dari kekuatan lain;

g) Sang mangupa dyaya, orang yang memberikan ilmu pengetahuan berupa pendidikan baik

h) jasmani maupun rohani;

i) Sang anyanaskara, orang yang memberikan kesucian pada rohani kita.

Kelima kewajiban tersebut sepatutnya dilakukan orang tua sebelum dibantu oleh orang lain sehingga menjadi orang tua yang sempurna mampu membahagiakan putra-putranya dalam segala situasi. Untuk itu hal yang terbaik adalah mendalami spiritual sejak masa muda agar bisa mengarahkan hidupnya menjadi lebih nyaman. Supardhi (2016 : 5) terkait dengan hal itu disebutkan bahwa.

Mengenai kegiatan pelaksanaan kegiatan spiritual didasarkan pada bukubuku suci yang sudah diterjemahkan sehingga memudahkan untuk memahami lebih dalam. Untuk pemahaman itu sebaiknya tidak dipelajari setengah-setengah, atau hanya dibibir saja untuk diucapkan namun benar-benar dilaksanakan dengan hati yang tulus. Pelaksanaan kegiatan tersebut dimuat dalam Upanishads; sehingga isi yang tertuang di dalam kitab itu sebagai hal yang otoritas dalam melakukan kegiatan spiritual, bukan sebagai suatu kepintaran atau kecakapan manusia dalam membuatnya namun merupakan wahyu yang datangnya dari Tuhan.

Sesungguhnya untuk mendapat sesuatu yang terbaik, salah satu jalan yang tepat adalah dengan meningkatkan spiritual melalui pendalaman hakikat yang terdapat dalam kitab suci untuk bisa menjalankan kehidupan sebagai manusia pancasilais, yang mampu menahan ego, keangkuhan dan kemarahan yang akan menjadikan manusia yang tidak beretika dan tidak memahami ajaran budi pekerti yang luhur, yang ujungnya menjadi hancurnya generasi sebagai sendi-sendi 
kebertahanan bangsa. Selain itu untuk meningkatkan nilai-nilai spiritual yang telah membudaya pada masyarakat Hindu di Bali dengan melakukan japa dengan Mantra Gayatri atau Gayatri Mantram. Sehubungan dengan hal itu, menurut Putra (2011 : 59) disebutkan bahwa.

Melalui japa Gayatri mantra yang akan membersihkan papa dan dosa yang telah dialami dan diperbuat sebelumnya. Dengan disiplinnya melakukan japa ini yang memiliki kedahsyatan dan anugerah pencerahan luar biasa yang akan menuntun manusia dari jalan yang tidak benar menuju jalan yang benar, disamping adanya kegelapan pikiran akibat adanya Awidya atau kebodohan, maka melalui mantra Gayatri ini mampu menuntunnya ke arah pencerahan dengan cahaya terangnya pengetahuan sehingga menjadikan manusia yang bijaksana yang mampu melebur ahamkara sebagai sumber konflik dan pertengkaran.

Semua itu dilakukan dengan penuh keyakinan, tidak bisa dipaksakan dan selalu dalam kondisi tanpa beban, sehingga yang muncul dalam diri adalah ketulusan dan penyerahan diri secara lapang. Jika hal tersebut telah dilaksanakan maka akan menjadikan diri pribadi yang penuh dengan kemandirian. Untuk itu bisa berbagi dengan manusia lainnya yang pemahamannya belum sejauh itu di lingkungannya sendiri, lalu meluas hingga kecamatan, kabupaten dan Provinsi maka akan tercapailah menjadi manusia Indonesia yang seutuhnya. Sebab menurut Hasibuan, (2002 : 91) disebutkan bahwa.

Manusia Indonesia itu adalah manusia yang mempunyai jiwa dan raga. Dan sesuai dengan pengakuan Bung Karno, Pancasila bukan hasil pemikiran sendiri. Namun Pancasila merupakan perpaduan berbagai agama besar yang berada di Indonesia seperti Islam, Nasrani, Katolik Hinduisme dan Budhisme. Melalui pelaksanaan kelima sila Pancasila itu maka tercapailah visi pembangunan nasional yakni terwujudnya masyarakat Indonesia yang damai, demokratis, berkeadilan, berdaya saing tinggi, maju dan sejahtera ....

Harapan mantan Presiden pertama kita sangat luar biasa daya pikirnya menuju masa depan sehingga tidak membedakan agama serte keyakinan yang satu dengan yang lain dan memahami adanya rasa Kebhinnekaan yang Tunggal Ika adanya. Hal ini yang patut dicontoh oleh masyarakat bangsa Indonesia sehingga bisa hidup berdampingan penuh kerukunan.

2. Fungsi Nilai-Nilai Luhur Pancasila tersebut Melalui Etika dan Budi Pekerti Bangsa dalam Aspek Sosial Budaya

Fungsi nilai-nilai luhur Pancasila tersebut memberikan pemahaman yang berarti bagi bangsa Indonesia utamanya akan membangkitkan semangat kebangsaan yang menjunjung tinggi harkat dan martabat nilai-nilai tradisional di masyarakat yang telah dilestarikan keberadaannya secara turun temurun oleh nenek moyang bangsa ini. Adapun fungsi nilai-nilai tersebut sebagai berikut.

\section{a. Fungsi Kegotongroyongan}

Terkait dengan fungsi kegotongroyongan di Bali sudah mendarah daging sejak masa lalu, berupa adanya acara-acara berupa upacara yadnya. Yadnya merupakan korban suci secara tulus iklas yaitu Dewa Yadnya (upacara korban suci kepada para Dewa berupa upacara piodalan di pura. Pitra yadnya (korban suci secara ikhlas kepada para leluhur. Rsi yadnya (Korban suci secara ikhlas kepada para Rsi. Manusa yadnya (Korban suci secara ikhlas kepada manusia sejak lahir hingga pernikahannya. Dan Bhuta Yadnya (korban suci secara iklas kepada para bhuta atau makhluk alam yang tidak bisa dilihat secara langsung). Kelima yadnya ini disebut dengan istilah Panca Yadnya. Dalam pelaksanaan upacara tersebut biasanya umat Hindu melakukannya berdasarkan hari baik dan dihadiri oleh keluarga besar baik masih dalam satu klen atau di luar klen. Hubungan kegotongroyongan itu berupa pembuatan sesajen khususnya bagi wanita dan bagi pria dengan membuat tempat berlindung berupa tribun dari 
anyaman bambu atau pun membuat bumbu masakan khas yang telah disiapkan sejak jam 3 pagi, baik untuk membuat sate maupun sayur urab yang akan dibagi-bagikan ke rumah saudara-saudaranya ketika sudah pagi hari. Jadi kegiatan itu sudah turun temurun dan sangat penuh dengan rasa kekeluargaan dan kegotongroyongan yang mendalam. Sehingga fungsi kegotongroyongan benar-benar berjalan sebagai mana mestinya dan lestari hingga kini. Jika dihubungkan dengan Pancasila maka akan terkait dengan sila ke tiga persatuan Indonesia karena melalui acara kegotongroyongan itu akan mewujudkan adanya persatuan visi dan misi untuk mewujudkan suksesnya kegiatan persaudaraan secara bersamaan.

b. Fungsi Pelestarian Alam

Melalui kegiatan upacara yadnya tersebut tentu menggunakan bahanbahan dari alam berupa air suci, daun-daun atau pun pohon-pohon tertentu, hewan -hewan juga digunakan baik ayam, itik, anjing, sapi hingga kerbau. Jadi menggunakan segala yang ada di alam tentu merupakan hasil karya Tuhan sebagai Maha Besar, maha segalanya, sehingga menggunakan hasil alam dan tidak mengabaikannya hingga rusak dan mati begitu saja atau membuangnya hingga hancur, namun sebaliknya memanfaatkannya untuk keselamatan alam pula melalui upacara. Sehingga sangat menghormati segala pemberian Tuhan terhadap alam ini dan mengucapkan terima kasih kepada alam beserta isinya yang sangat bermanfaat bagi manusia melalui upacara yang dihaturkannya. Hal itu dilakukan berdasarkan atas Tri Hita Karana. Umat Hindu mengajarkan kepada kita mengenai konsep Tri Hita Karana yang artinya tiga penyebab kesejahteraan yaitu Parhyangan, Pawongan, Palemahan. Parhyangan artinya manusia hendaknya menjaga keharmonisan dengan Tuhan dapat diimplementasikan melalui upacara-upacara keagamaan, sembahyang, beryajna, dan lain-lain. Pawongan artinya manusia hendaknya menjaga. Untuk itu jika dikaitkan dengan Pancasila hal ini masuk pada sila pertama Pancasila yaitu Ketuhanan yang Maha Esa.

\section{c. Fungsi Kebahagiaan Jasmani dan Rohani}

Dengan dilaksanakan segala kegiatan yang mentradisi di Bali ini maka kerukunan pada umumnya berjalan seimbang antar agama, antar klen, antar wilayah walau ada hal sedikit yang perlu dicari solusinya namun terlihat masih rukun-rukun saja. Permasalahan selalu ada saja yang menjadikan makin dewasanya manusia akan tantangan-tantangan alam untuk dicari solusinya. Pada dasarnya pertentangan selalu ada dan yang dijadikan batasan adalah agar tidak menimbulkan permasalahan yang kompleks. Harus ada penengahnya yang mampu sebagai tauladan dalam pelaksanaannya. Sehingga tercapai kemufakatan atau hasil yang keputusan yang maksimal sebagai pedoman bagi seluruh masyarakat di lingkungannya. Hal ini termasuk dalam sila keempat Pancasila yaitu Kerakyatan yang dipimpin oleh hikmat kebijaksanaan dalam permusyawaratan / perwakilan, juga terkait dengan sila ke lima pula yaitu keadilan sosial bagi seluruh rakyat Indonesia.

\section{Makna yang tersirat dalam internalisasi nilai- nilai luhur Pancasila}

Makna memberikan sesuatu arti yang majemuk yang mengisyaratkan dalamnya pengetahuan yang ada dan sifatnya tersembunyi, namun terungkap lewat wawasan pembahasnya hingga memberikan arti yang selaras dan seimbang. Dalam hal ini makna yang tersirat dalam internalisasi nilai- nilai luhur Pancasila tersebut sebagai berikut.

\section{a. Makna Kebersamaan dan Solidaritas}

Makna kebersamaan memberi arti dalam hal ini, keluarga sebagai pembentuk kharakter keturunannya diharapkan mampu memberikan petunjuk atau pun saran demi kemajuan masa depannya. Makna kebersamaan ini 
dikaitkan dengan makna solidaritas. Kebersamaan yang solid satu sama lain tidak adanya pertentangan namun menerima segala keputusan bersama sebagai sebuah aturan baru yang mengikat. Pancasila pun telah mengajarkan sikap-sikap tersebut melalui ajaran-ajaran orang tua juga ajaran para guru serta petunjuk pemerintah guna mempertebal rasa persaudaraan memenuhi sila ke tiga dari Pancasila yaitu persatuan Indonesia yang mesti ditingkatkan di masyarakat, sehingga tidak terjadi jurang pemisah antara si kaya dan si miskin. Sehubungan dengan hal itu, untuk mengambil kepeutusan bersama yang dilakukan di Bali biasanya di lakukan pula melalui azas kebersamaan ketika salah satunya melalui rapat-rapat di balai desa, sehingga meminimize permasalahan adat ke depannya.

\section{b. Makna Kekuatan}

Mengenai makna kekuatan bisa memberikan semangat hidup yang lebih baru. Kekuatan datangnya melalui alam dan melalui diri pribadi. Jika kekuatan melalui alam sebagai milik Tuhan yang Maha Esa. Jika kekuatan dari diri sendiri biasanya datangnya dari kemauan dan bisa diterima dengan akal sehat melalui pikirannya. Salah satu kekuatan yang dilakukan adalah melalui yoga dan meditasi. Yoga dan meditasi telah lama berkembang dan banyak pula orang yang mengenalnya.

Yoga menurut https://www.kajianpustaka.com/2018/04/pengertian-jenistujuan-dan-manfaat-yoga.html Yoga adalah sebuah ilmu yang memberikan petunjuk berupa penjelasan yang berkaitan antara fisik, mental, dan spiritual manusia untuk mencapai sistem kesehatan menyeluruh (holistik) yang terbentuk dari kebudayaan India kuno. Yoga pertama kali diperkenalkan dalam buku Yoga Sutras yang ditulis oleh patanjali, yaitu seorang tokoh legenda dari India yang hidup sekitar 200 hingga 500 SM (Sindhu, 2014:30).

Hal ini jika telah dilaksanakan dengan baik, maka segala hal yang dianggap sebagai beban di depan mata akan serasa sirna dan jika masih akan terasa ringan dan mudah di atasi dengan baik. Jika Yoga dan meditasi selalu dilakukan maka akan mendapat faedahnya sesuai dengan kebutuhan elemenelemen pada tubuh. Baik terkait dengan kekuatan dalam berpikir, maupun kekuatan dalam menjalani kehidupan sehingga akan menjadi semakin baik. Melalui hal itu kekuatan dari masing-masing bisa disatukan sebagai sebuah kebulatan tekad sebagai mana tercermin dalam sila persatuan Indonesia. Sebagaimana menurut Mastuti dan Hastho Bramantyo (2009 : xxii) terdapat dalam Kekawin Sutasoma karangan Mpu Tantular, berupa bhineka tunggal ika tan hana dharmma mangrwa (139.5) yang diangkat sebagai semboyan bangsa Indonesia yang diabadikan dalam lambang negara Garuda Pancasila.

\section{SIMPULAN}

Pemahaman nilai-nilai Pancasila melalui pendidikan budi pekerti cukup luas pandangannya terkait dengan memahami Panca Widha, memahami mantra Gayatri. Dan Fungai nilai- nilai Pancasila berupa fungsi kegotongroyongan, fungsi pelestarian alam serta fungsi kebahagiaan jasmani maupun rohani. Serta pemahaman Tri Hita Karana. 
DAFTAR PUSTAKA

Hasibuan, Sofia Rangkuti. 2002. Manusia dan kebudayaan di Indonesia Teori dan Konsep. Jakarta : PT. Dian Rakyat.

Kadjeng, I Nyoman, dkk. 2005. Sarasamuccaya. Surabaya : Paramita.

Mastuti, Dwi Woro Retno \& Hastho Bramantyo. 2009. Kakawin Sutasoma Mpu Tantular.

Depok : Komunitas Bambu.

Putra, I Nyoman. (2011). Maha Dahsyat Gayatri Mantra Menepis Badai Mantra Untuk mendapatkan Kedamaian Hidup. Surabaya : Paramita.

Wiana, I Ketut. (2004). Mengapa Bali disebut Bali? Surabaya : Paramita.

Yupardhi, W. Sayang. (2016). Intisari Upanisad. Surabaya : Paramita.

Sisil. (2018). https://si.ittelkom-pwt.ac.id/2018/03/03/perkembangan-teknologiinformasi-masa-kini/

https://www.kompasiana.com/dupamarch/5ca5988a95760e5b54659332/implementasiajaran-tri-hita-karana-terhadap-keseimbangan-alam

https://brainly.co.id/tugas/6929879

https://www.kajianpustaka.com/2018/04/pengertian-jenis-tujuan-dan-manfaatyoga.html 